\title{
Investigation of European shot-hole borer, Xyleborus dispar (Coleoptera, Scolytidae), in apple orchards of Latvia
}

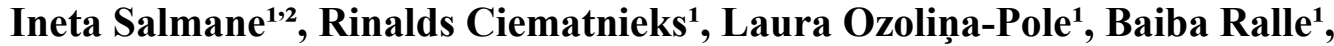 \\ Gederts Ievinsh' \\ ${ }^{1}$ Latvian Plant Protection Research Centre, \\ Address: 14A Struktoru Str., Riga, , LV-1039Latvia \\ ${ }^{2}$ Institute of Biology, University of Latvia, \\ Address: 3 Miera Str., Salaspils, Latvia, LV-2169
}

\begin{abstract}
European shot-hole borer is known to occur on a wide range of deciduous trees and frequently found on fruit trees in most of the Holarctic. During the last years increased activity of this beetle contributed necessity for investigation of it in apple orchards of Latvia. Because of the latent behavior it is difficult to control distribution of Xyleborus dispar. Often insecticides are not effective, especially if not used in an appropriate time and methods of integrated or biological plant protection are needed. In the current study, results of two year monitoring of $X$. dispar flying activity and effectiveness of two types of sticky traps, Rebell Rosso and Csalomon Palx, bitted with $50 \%$ alcohol are presented. Four traps of each type were placed in each orchard at the beginning of May in 2013 and at the middle of April in 2014. Differences among respective orchards were recorded: the highest number of beetles was found in the largest orchard surrounded by wide deciduous forests; the lowest number was recorded in the orchard surrounded by the agricultural lands. The first emerging $X$. dispar female was caught at the middle of April. During the vegetation season the highest flying activity of beetles was at the end of April - beginning of May $\left(17^{\text {th }}-18^{\text {th }}\right.$ week). Afterwards number and flying activity of beetles decreased and at the middle of June $\left(25^{\text {th }}-26^{\text {th }}\right.$ week) reached zero. In orchard with the highest number of European shot-hole borer, significantly higher number of beetles was recorded on Rebell Rosso traps; for the rest two orchards higher number of $X$. dispar was recorded on Csalomon Palx traps.
\end{abstract}

Keywords: ambrosia beetle, sticky traps, monitoring.

\section{INTRODUCTION}

Ambrosia beetle, European shot-hole borer Xyleborus dispar $\mathrm{F}$. is known to occur on a wide range of deciduous trees and frequently is found on fruit trees in most of the Holarctic. $X$. dispar attacks almost all deciduous tree species in the forests, as well as city-growing trees like Crataegus, Sorbus, Acer, Castanea [1,2]. This beetle is an important pest in orchards and vineyards in Europe [3-11]. Young apple, pear and stone-fruit trees are those mainly attacked by $X$. dispar and sometimes damage caused in orchards results in significant yield losses [10,12].

Ambrosia beetles spend their entire life within a woody stem and generally prefer weakened or stressed trees [10]. In spring, first adult females emerge at temperatures $14-20{ }^{\circ} \mathrm{C}[9,13]$, fly for considerable distance and make holes in sapwood, where they lay eggs and a new generation develops. Imagoes overwinter within the sapwood galleries. $X$. dispar establishes a complex symbiosis with fungus
Ambrosiella hartigii that allows larvae to develop in wood tissues, which are poor in nutrients [6].

There are no studies in Latvia concerning the European shot-hole borerdistribution. However, some authors have mentioned these beetles as pests in orchards [14-16]. According to the recent observations, the damage of $X$. dispar is gradually increasing [17, Salmane et al. unpublished data].

The development of insecticide resistance and concern about the detrimental effects of these chemicals on non-target arthropods, the environment, and human health have increased interest in alternative insect control agents [8]. There are very few publications on use of ethanol-baited traps for Scolytidae attraction purposes in Europe (Slovakia, France and Greece) [18-20]. Ambrosia beetles are attracted to ethanol because of their preference for aged wood characterized by anaerobic respirationgenerated ethanol [20-22].

The aim of the present study was to monitor flying activities of $X$. dispar and effectiveness of two types 
of sticky traps in limiting the numbers of these pests in orchards in conditions of Latvia.

\section{MATERIALS AND METHODS}

This study was conducted in the three commercial orchards of Latvia and during the 2013 and 2014 monitoring of Xyleborus dispar was performed. The study was conducted in Jelgava, Beverina and Talsi municipality to cover various climate conditions (Fig.1).

Two types of traps, Rebel Rosso (Andermatt Biocontrol, Switzerland) and Csalomon Palx (Plant Protection Institute, Czech Republic) sticky traps with 1 liter plastic bottles bitted with 50\% alcohol were used. Four traps of each type were placed at each apple orchard in two parallel lines and hung out about $1 \mathrm{~m}$ above the ground. Alcohol was changed every week during the assessment time. Traps were placed in the apple orchards at the April 30 and May 1 in 2013 and on April 8-9 in 2014. Assessment was made once a week and beetles were counted until no beetles were found. Means and standard deviations were calculated using Excel (Microsoft Corporation). Significant differences between trap types, orchards and in respect to time were evaluated by ANOVA using a Tukey-Kramer test. Correlation between the number of insects and climate variables was estimated using KaleidaGraph 4.5 (Synergy Software).

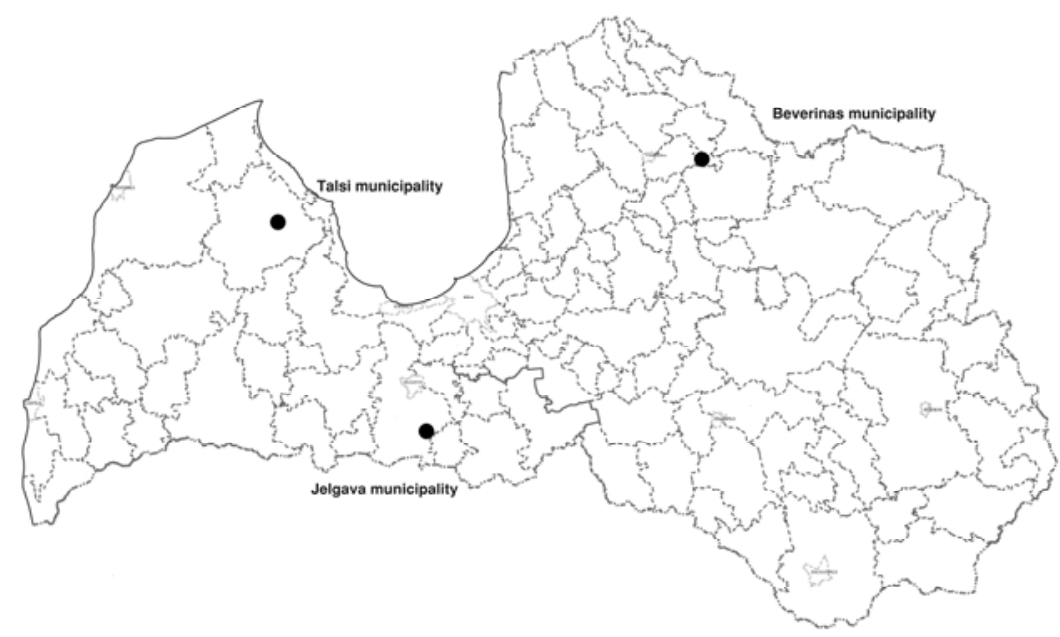

Fig. 1. Map of Latvia with location of study sites.

\section{RESULTS AND DISCUSSION}

In 2103, sticky traps were installed in time which already coincided with a peak of flight activity of $X$. dispar adult females, as indicated by the number of captured insects (Fig. 2). In 2014, traps were installed before any flight activity of $X$. dispar started.

The overall tendency was to have higher numbers of captured $X$. dispar individuals on Csalomon Palx traps. The total number of individuals on Rebel Rosso traps was 2862 and 4376, in 2013 and 2014, respectively, while it was 4893 and 5741 on Csalomon Palx traps. However, statistically significant higher average number of captured individuals on Csalomon Palx traps in 2013 was found only on week 19 in Beverina municipality and Jelgava municipality, and in 2014 on week 17 in Jelgava municipality, and on week 21 in both Beverina municipality and Talsi municipality. In contrast, statistically significant higher number of captured individuals on Rebel Rosso traps was found in 2013 in Beverina municipality on weeks 21 and 22, and in Talsi municipality from week 19 till 23.
Comparing the efficiency of different sticky trap types, the total number of $X$. dispar caught by Csalomon Palx was higher in both 2013 and 2014. Still significantly higher number of beetles on these traps was found on separate weeks more related to the beginning of flying activity, and significantly higher number of $X$. dispar on Rebell Rosso traps was found in few weeks at the middle or closer to the end of the flying period. Some authors have admitted Rebell Rosso traps as the most efficient and practical trap type $[11,13,20,23]$. Rebell Rosso sticky traps have been compared with Mastrap L traps and considered to be more efficient [6] or equially efficient [9] in hazelnut plantations. However, modified Mastrap L traps are considered to be more selective and friendly to the environment, as other insect species are captured by red winged traps in addition to $X$. dispar [9]. Some other authors suggest that Rebell Rosso traps are not as efficient as funnel-type and ribbed cage traps [5]. In the present study it seems that in the case of high flying activity both types of traps are equal or Rebell Rosso are more efficient, but in the case of low activity Csalomon Palx traps are more efficient. 
In both years, significantly higher number of $X$. dispar was captured in orchard in Talsi municipality, 5488 and 5383 individuals in 2013 and 2014, respectively, in comparison to Beverīna (1287 and 3268) and Jelgava (980 and 1466) municipality. The assessed orchards were situated in various climate and landscape conditions. Orchard in Jelgava municipality is surrounded by agricultural lands, near orchard only single old lime-trees and oaks are located. Probably that is a main reason why the least number of $X$. dispar was caught there (Fig. 2A). Orchard in Beverina municipality is surrounded by fragmentary mixed-pine forests, but along the one of the longest sides are growing row of tall deciduous trees. The higher number of beetles was recorded there in comparison to previous orchard, still it was almost half of the number found in Talsi municipality (Fig. $2 \mathrm{~A}, \mathrm{C})$. Higher number of beetles was recorded in 3 of 8 traps, located closer to the large deciduous trees. Orchard in Talsi municipality is densely surrounded by wide deciduous forests and by fruit orchard from one of sides. The highest number of $X$. dispar was recorded in this orchard. It is well known that the European shot-hole borer attacks many deciduous tree species and closeness of forests may significantly increase number of $X$. dispar in orchards, as they prefer sunny and dry places instead of shaded forests $[2,7,12,24]$. Consequently, closeness of orchard to forest can directly increase the number of beetles caught in traps.

There were pronounced differences in flight activity of European shot-hole borer between two years. In 2014 it started earlier and had two temporarily separated peaks in all three sites. While the first maximum of flight activity coincided for the sites, the second peak occurred on different weeks. The differences of flight activity in timing in 2013 and 2014 were related to differences in respective climatic conditions between the two years and are analyzed in more detail for 2014 .

The first flight activity coincided with the increase of average air temperature above some threshold value, which was $10.0,10.6$ and $9.3^{\circ} \mathrm{C}$ in the case of Beverina (Fig. 3A), Jelgava (Fig. 4A) and Talsi apple orchard (Fig. 5A), respectively. The first peak of flight activity coincided with relatively low average air humidity (part $\mathrm{B}$ of the respective figures) and low level or even no rainfall (part $\mathrm{C}$ of the respective figures). However, the number of captured individuals started to decrease in the second (Jelgava and Talsi orchard) or in the third week (Beverina orchard) of active flight, which coincided with decrease in average temperature as well as increase in both air humidity and the amount of rainfall. The second peak of flight activity coincided with low air humidity in Beverina and Talsi orchards but not in Jelgava. In Jelgava site active flight was evident even in the week with relatively high rainfall level.
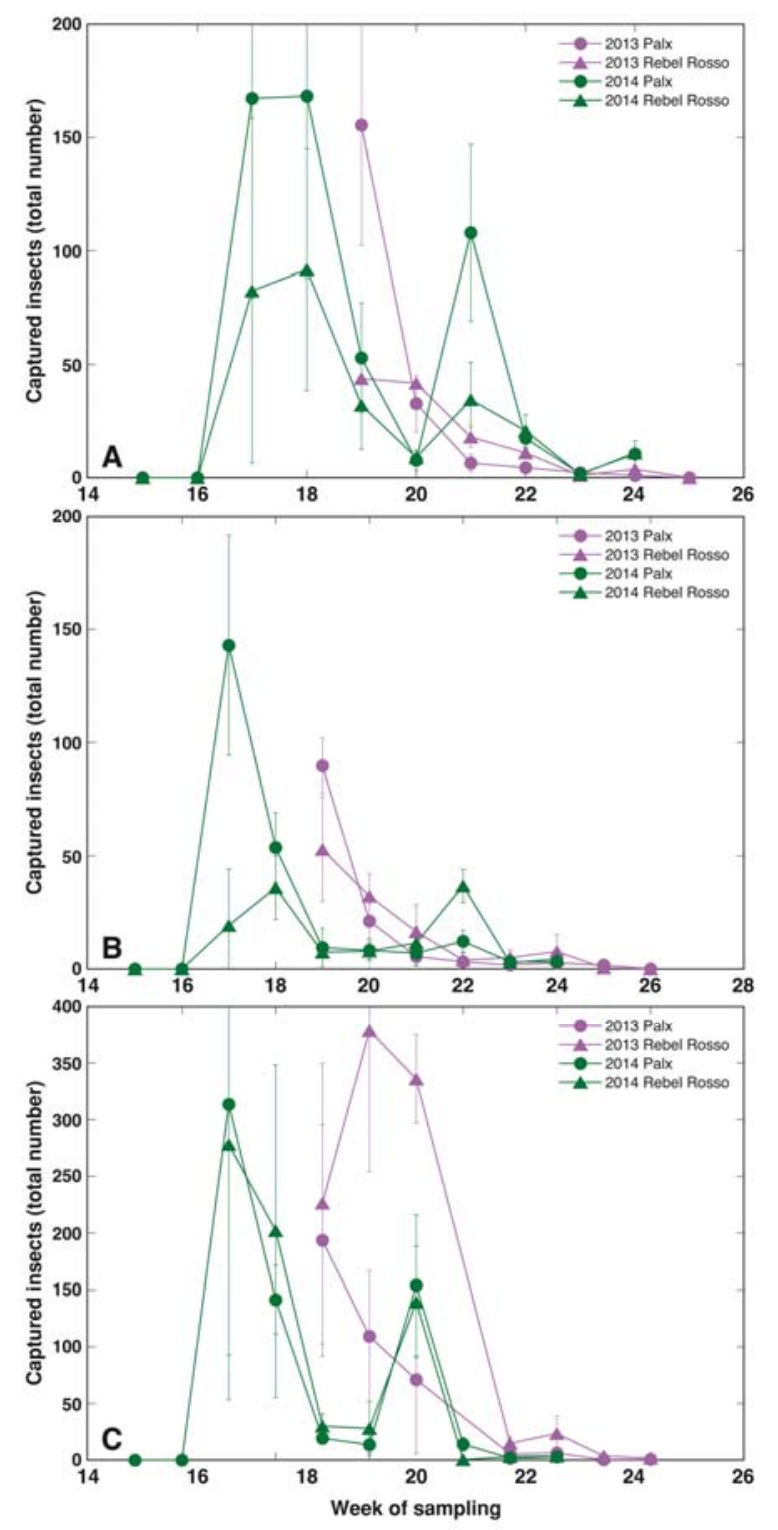

Fig. 2. Comparison of captured number of $X$. dispar individuals depending on trap type and year of study in different sites. A, Beverina municipality; B, Jelgava municipality; C, Talsi municipality. Data are means $\pm \mathrm{SD}$.

Because of the evidently complex relationship between the flight activity of $X$. dispar from one side and average temperature, air humidity and the amount of precipitation from the another, the correlation between the activity and climate variables was relatively low $(R=0.26, R=0.15, R=0.34$, for temperature, humidity and precipitation, respectively). Several authors have noted a negative correlation between rainfall and flying activity of European shothole borer $[6,9,24]$. In the present study one case at Jelgava municipality was found with active beetle flight during the rainy period. Possibly the more active rain was at night hours while $X$. dispar is capable for active flying only during the daytime. 
Time of emergence of adult females is various depending on weather conditions of the respective season as well as on North-South location. Dependence of the start of flight activity on the average air temperature in spring was shown by several authors. In more southern-situated regions like Italy, Turkey, Switzerland this temperature threshold was higher, $18-22{ }^{\circ} \mathrm{C}$, in comparison to northward, above $10^{\circ} \mathrm{C}[3,13,11,24]$.
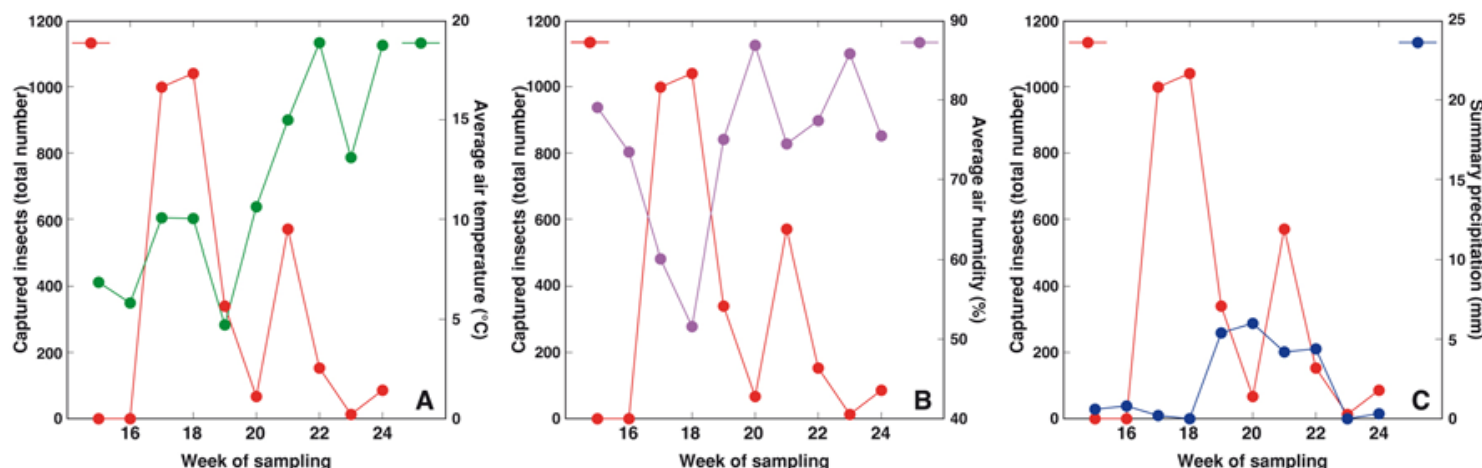

Fig. 3. Relationship between the total number of captured $X$. dispar individuals and average air temperature (A), average air humidity (B) and summary precipitation (C) on site in Beverīna municipality in 2014.
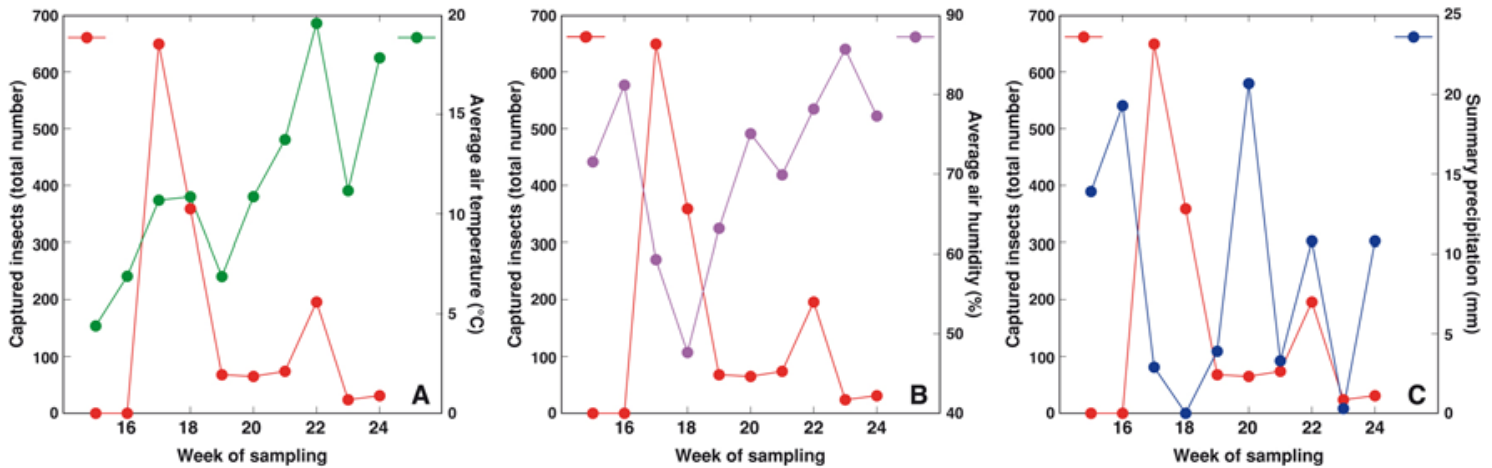

Fig. 4. Relationship between the total number of captured $X$. dispar individuals and average air temperature (A), average air humidity (B) and summary precipitation (C) on site in Jelgava municipality in 2014.
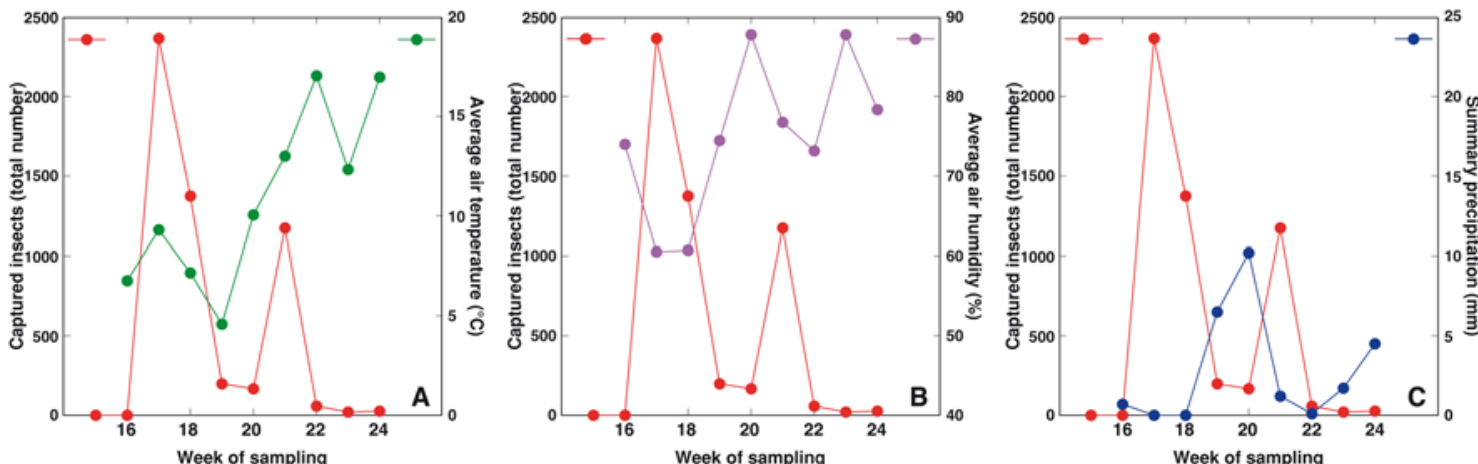

Fig. 5. Relationship between the total number of captured $X$. dispar individuals and average air temperature (A), average air humidity (B) and summary precipitation (C) on site in Talsi municipality in 2014.

\section{CONCLUSIONS}

Number of the Xyleborus dispar was significantly higher in orchard located close to the forest, especially deciduous one. Single large deciduous trees also may play impact on $X$. dispar reproduction and dispersal. Flying activity is affected by climatic conditions in long term, as well as in the respective day. The first emerging $X$. dispar was caught at the middle of April in 2014. During the vegetation season the highest flying activity of beetles was at the end of April beginning of May $\left(17^{\text {th }}-18^{\text {th }}\right.$ week). Afterwards number and flying activity of beetles decreased and at the middle of June $\left(25^{\text {th }}-26^{\text {th }}\right.$ week $)$ reached zero. In orchard, where the highest number of European shothole borer was found, higher number of beetles was recorded on Rebell Rosso traps, in the rest two 
orchards higher number of $X$. dispar was recorded on Csalomon Palx.

\section{ACKNOWLEDGEMENTS}

This study was performed by the project $\mathrm{Nr}$. 211211/c-120 funded by the Ministry of Agriculture, Latvia.

\section{REFERENCES}

[1] Nachtigall G. Secondary damage to trees. Gartenamt 42, 1993, pp. 101-102.

[2] Bociort M., Marinescu M. Research on controlling Anisandrus dispar (Scolytidae) in orchard from Carand village, Arad county, Romania. Studia Universitatis "Vasile Goldis", Seria Stiintele Vietii 21, 2011, pp. 739-744.

[3] Viggiani G. The attacks of Anisandrus dispar on hazel tend to spread. Informatore Agrario 35, 1979, pp. 5335-5357.

[4] Hesjedal K., Edland T. Attack of the decid uous tree barkbeetle in fruit orchards. Gartneryrket 78, 1988, pp. 115-117.

[5] Ak K., Saruhan I., Akyol H. Determination of performance of different trap types against Xyleborus dispar (Fabricius, 1792) and Xyleborinus saxesenii (Ratzeburg, 1792) (Coleoptera: Curculionoidea: Scolytidae). Anadolu J. Agr. Sci. 29, 2014, pp. 26-35.

[6] Bucini D., Balestra G.M., Pucci C., Paparatii B., Speranza S., Zolla C.P., Varvaro L. Bio-ethology of Anisandrus dispar F. and its possible involment in Dieback (Moria) diseases of hazelnut (Corylus avelana L.) plants in Central Italy. Acta Horticult. 686, 2005, pp. 435-443.

[7] Pavlin K., Tomše S. Monitorng of ambrosia beetle Xyleborus dispar F. and leopard moth Zeuzera pyrina L. in intensive plantation in region of Dolenjska, Bela Krajini in Posavju. Lectures and papers presented at the $7^{\text {th }}$ Slovenian Conference on Plant Protection, Zreče, Slovenia, 2005, pp. 464-469.

[8] Sezen K., Muratoglu H., Nalcacioglu R., Mert D., Demirbag Z., Kati H. Highly pathogenic Bacillus thuringiensis subsp. Tenebrionis from European shot-hole borer, Xyleborus dispar (Coleoptera: Scolytidae). New Zealand J. Crop Hortic. Sci. 36 2008, pp. 77-84.

[9] Speranza S., Bucicni D., Paparatti B. New observation on biology of European shot-hole borer (Xyleborus dispar (F.)) on hazel in North Latium (Central Italy). Acta Hortic. 845, 2009, pp. 539-542.

[10] Cebeci H.H., Ayberk H. Ambrosia beetles, hosts and distribution in Turkey with a study on the species of Istanbul province. African J. Agric. Res. 5, 2010, pp. 1055-1059.
[11] Saruhan I., Akyol H. Monitoring population density of Anisandrus dispar and Xyleborinus saxesenii (Coleoptera: Scolytinae, Curculionidae) in hazelnut orchards. African J. Biotechnol. 11, 2012, pp. 4202-4207.

[12] Schaal G. The Bark-beetle, Xyleborus dispar. Dtsch. Obstbauztg. Jena, 1923, pp. 205-206.

[13] Mani E., Remund U., Schwaller F. Attack of the bark beetle, Xyleborus dispar F., (Coleoptera: Scolytidae) in orchards and vineyards. Importance, biology, flight observations, control, development and use of an efficient ethanol trap. Acta Phytopathol. Entomol. Hung. 27, 1992, pp. 425-433.

[14] Šmits V. Mizgrauži. Latvijas Valsts izdevniecība, Rīga, 1960, $208 \mathrm{p}$.

[15] Ozols E. Lauksaimniecības entomoloǵija. 3. izdevums. Zvaigzne, Rīga, 1973, 496 p.

[16] Rupais A. Kokaugu kaitēkḷu sugu noteicējs pēc bojājumiem augḷu dārzos un apstādījumos. Valsts Augu aizsardzības dienests, Rīga, 1999, 273 p.

[17] Ak K., Uysal M., Tuncer C., Akyol H. The bark beetle species (Coleoptera: Scolytidae) harmful on hazelnut in middle and east Blacksea region of Turkey and their control strategies. S.U. Ziraat Fakultesi Dergisi 19, 2005, pp. 37-40.

[18] Markalas S., Kalapanida M. Flight pattern of some Scolytidae attracted to flight barrier traps baited with ethanol in an oak forest in Greece. J. Pest. Sci. 70, 1997, pp. 55-57.

[19] Bouget C., Noblecourt T. Short-term development of ambrosia and bark beetle assemblages following a windstorm in French broadleaved temperate forest. J. Appl. Entomol. 129, 2005, pp. 300-310.

[20] Galko J., Nikolov C., Kimoto T., Kunca A., Gubka A., Vakula J., Zubrik M., Ostrihon M. Attraction of ambrosia beetles to ethanol baited traps in a Slovakian oak forest. Biology 69, 2014, pp. 1376-1383.

[21] Graham K. Anaerobic induction of primary chemical attractancy for ambrosia beetles. Can. J. Zool. 46, 1968, pp. 905-908.

[22] Miller R.D., Rabaglia J.R. Ethanol and (-)- $\alpha$-pinene: attractant kairomones for bark and ambrosia beetles in the southeastern US. J. Chem. Ecol. 35, 2009, pp. 435-448.

[23] Saruhan I., Akyol H. Monitoring population density and fluctuations of Xyleborus dispar and Xyleborinus saxesenii (Coleoptera: Scolytidae) with red winged sticky traps in hazelnut orchards. African J. Agric. Res. 8, 2012, pp. 2189 2194.

[24] Bhagwandin H.O.Jr. The shot hole borer: An ambrosia beetle of concern for chestnut orcharding in the Pacific Northwest. $93^{\text {rd }}$ Annual Report of the Northern Nut Grower's Association. 1992, pp. 168-177. 